\title{
Carbon dioxide emissions embodied in international trade in Central Europe between 1995 and 2008
}

\author{
Jana VLČKOVÁ ${ }^{\mathrm{a} *}$, Vojtěch NOSEK ${ }^{\mathrm{b}}$, Josef NOVOTNÝ ${ }^{\mathrm{b}}$, Antonín LUPÍŠEK ${ }^{\mathrm{c}}$
}

\begin{abstract}
Climate change and environmental policies are widely discussed, but much less is known about emissions embodied in goods traded internationally, and the distinction between emission producers and consumers. The carbon dioxide emissions embodied in international trade in Central European countries are subject to examination in this paper. As a result of industrial restructuring and environmental legislation, air pollution has improved significantly in Central European countries since the 1989 transition. On the other hand, economic growth has been accompanied by a rise in consumerism. Despite the increasing role of exports, the Visegrad group countries have become net importers of carbon dioxide emissions between 1995 and 2008. This seems to be the 'standard trajectory' of a country's transition toward a more developed and consumption-oriented economy. The global patterns of carbon dioxide emissions embodied in manufacturing exports are also mapped, using network analysis and constructing 'product space'. The analysis confirms that industrial re-structuring played an important role in lowering the production of carbon dioxide emissions in the Visegrad countries.
\end{abstract}

Keywords: carbon dioxide, embodied emissions, international trade, revealed comparative advantage, product space, Visegrad Group countries

\section{Introduction}

Climate change and environmental protection have attracted a lot of attention, and the Kyoto protocol, part of the United Nations Framework Convention on Climate Change, sets obligations on binding countries to reduce greenhouse gases (GHGs) emissions. The GHG emissions are increasing at the global scale, particularly in developing countries (Raupach et al., 2007). Developed countries (Annex I countries) are given a quantified emission limitation, but developing countries do not have emission commitments to allow for economic development (Gutman, 1994). A reduction of emissions in Annex I countries is often offset by the relocation of production or by import substitution. And since goods traded internationally are on average more carbon-intensive, most of the production of highly carbonintensive goods is relocated (Ahmad and Wyckoff, 2003). Consequently, GHG emissions could increase globally even if the goals set in the Kyoto protocol are fulfilled. International trade is increasing much faster than world output: between 1995 and 2008, world trade increased by 6\% on average, whereas the world output gained only $3.1 \%$ (WTO, 2012). Thus, one should focus not only on carbon dioxide emissions production but also on studying carbon dioxide consumption and trade.

Central and Eastern European countries suffered from many environmental problems during the socialist period and air pollution was probably the most important. After 1989, these economies have integrated themselves into the global economy and have become highly export-oriented. Their export orientation, in both geographic and sector terms, has changed significantly. As well, more attention was given to the environment: new legislation, "cleaner" technologies, and the decreasing importance of heavy industry contributed to improvements in air pollution. On the other hand, there was growth in the number of passenger cars and in consumerism in general, trends which are associated with higher $\mathrm{CO}_{2}$ consumption. Therefore, exploring carbon dioxide production and consumption in these countries is highly interesting. The main goal of this paper is to study: (i) the carbon dioxide emissions embodied in international trade, with special attention to selected Central European countries (the so-called Visegrad countries); and (ii) to map the exports of carbon dioxide emissions from manufacturing in particular product groups, using network visualizing relatedness between products traded in the global economy. We are focusing on the evolution of these patterns between 1995 and 2008, both globally and at specific regional/ national levels. We apply the product space concept (e.g. Hidalgo et al., 2007) to compare $\mathrm{CO}_{2}$ emissions embodied in goods that are traded internationally.

\section{Theoretical background}

\subsection{International trade and the Visegrad countries}

In the past 30 years we have witnessed significant changes in the patterns of international trade. Traditionally, exports of developing countries were based on primary commodities. Manufacturing goods were produced mainly in developed countries. Furthermore, final goods have been mostly traded internationally. Due to globalization, the rise of TNCs (Trans-National Corporations) and value chains, huge changes in the world economy occurred (Dicken, 2007). A substantial part of the production has been relocated to developing and emerging economies. This has been intensified by the spatial separation of production and consumption.

\footnotetext{
${ }^{a}$ Department of World Economy, Faculty of International Relations of the University of Economics, Prague, Czech Republic (*corresponding author: J. Vlčková, email: jana.vlckova@vse.cz)

${ }^{\mathrm{b}}$ Department of Social Geography and Regional Development, Faculty of Science, Charles University in Prague, Czech Republic

${ }^{c}$ University Centre for Energy Efficient Buildings, Technical University in Prague, Czech Republic
} 
Since the $1980 \mathrm{~s}$, the trade flows have changed dramatically. This was caused by the rapid growth of many developing economies, China in particular. Later, due to the disintegration of the Eastern European bloc, new markets and exporters emerged in Central and Eastern Europe. In this paper, we focus on the Central European countries - the so called Visegrad countries ${ }^{1}$ (hereinafter V4 countries). In general, these countries had been highly industrialized and, during the Soviet period, heavy industry was primarily supported. Therefore, given their industrial traditions, an inexpensive and qualified labour force, and locations close to the Western European economies, these countries had started to attract foreign direct investments (FDI) inflows since the 1990s, especially from the Western European economies (Pavlínek et al., 2009). Furthermore, their relative political and economic stability was amplified by their preparations for EU accession, which occurred in 2004. In all V4 countries, manufacturing and exports play an important role. Exports now account for over $75 \%$ of GDP in all V4 countries except Poland, and employment in manufacturing exceeds $30 \%$ and accounts for $20-25 \%$ of GDP (World Bank, 2015). The V4 countries have become integrated into the global economy and global value chains, and Germany is now the major export destination. This means that their exports incorporate intermediate inputs produced in other countries. Because of these huge changes in the export orientation of V4 countries, changes in exported emissions are to be expected.

Recently, a new set of trade models has been built around the heterogeneity of skills and technologies consistent with emerging patterns of outsourcing (Grossman and Rossi-Hansberg, 2006; Bivens, 2007). In general, countries that export more sophisticated goods have experienced faster economic growth (Fagerberg, 1994; Grossman and Helpman; 1994). At the outset, however, production of a new type of a product is for the first time associated with cost uncertainty; specific factor endowments and an institutional context is required. Countries thus cannot produce and export the goods they might wish, they can only produce the goods for which they have productive knowledge. According to Hidalgo et al. (2007), countries tend to produce similar products that are close to the productive knowledge they already possess. The product space concept is a network of products, where products are connected based on the probability that the same country has developed revealed comparative advantage in these products (export specialisation). Products that require similar capabilities tend to build clusters. We assume that this pattern holds also for carbon dioxide emissions embodied in international trade.

\subsection{Carbon dioxide emissions}

Many studies have looked at the role of pollution embodied in international trade. Most of them focus on air pollution, although some studies include water or land pollution as well (Hoekstra and Hung, 2005; Hubacek and Giljum, 2003). In these research contributions, the balance of emissions embodied in international trade offers an insight into the environmental separation between domestic consumption and global production of GHGs. Such a balance also provides useful information about whether the pollution has been reduced or rather relocated. Carbon leakage is often used to describe the relocation of production. It is defined as "the part of emissions reductions in Annex I countries that may be offset by an increase of the emissions in the nonconstrained countries above their baseline levels." (Metz et al., 2007: 811).

Peters et al. (2011) found that carbon leakage is responsible for $16 \mathrm{Gt}$ of carbon dioxide (approximately 50\% of the annual global emissions of carbon dioxide) relocated from Annex I to non-Annex I countries from 1990 to 2008. It has not been demonstrated, however, that production has shifted due to environmental legislation (Peters and Hertwich, 2008). Economic reasons are much more important, although both motives are interconnected. Neither is environmental legislation sufficient to promote innovation (Hemmelskamp, 1997). In general, policies aimed at reducing emissions from electricity generation at a country level have impacts on prices of electricity.

It is thus important to find out how much of the nonAnnex I production is consumed in Annex I countries. Production-based emissions are total domestic emissions produced in a country, consumption-based emissions are emissions consumed in a country regardless of the place of production. Peters and Hertwich (2008) found that, based on international trade among 87 countries in $2001,21.5 \%$ of global carbon dioxide emissions (5.3 Gt) were embodied in international trade. According to them, Annex I countries exported $18.9 \%$ of carbon dioxide, and non-Annex I - 25.3\%. Annex I countries can be thus considered as net importers of carbon dioxide emissions. In an earlier study based on 24 countries, Ahmad and Wyckoff (2003) found that emissions embodied in net imports of OECD countries were equivalent to $2.5 \%$ of global carbon dioxide emissions in 1995. Net emissions transfer in international trade from developing to developed countries increased from $0.4 \mathrm{Gt}$ of carbon dioxide in 1990 to $1.6 \mathrm{Gt}$ in 2008 , and their share in global carbon dioxide emissions increased from $20 \%$ to $26 \%$ (Peters et al., 2011). Measuring the carbon footprint for individual products has recently increased public awareness of the carbon dioxide emissions embodied in trade.

Increase in trade leads to an increase of emissions embodied in trade. On the other hand, technology transfer from less carbon-intensive (developed) to more carbonintensive (developing) countries leads to a reduction of global emissions (Nakano et al., 2009). In developing countries, however, the decrease of carbon dioxide emissions per unit of GDP can be attributed not only to technological changes related mostly to more efficient resources use, but also to structural changes related to the increasing production of goods that are less carbon-intensive.

As a result of its enormous production growth, China, currently the world's largest exporter (in international trade and also in carbon dioxide emissions) has attracted a lot of attention (e.g. Lin and Sun, 2010; Peters et al., 2007). In this study, we focus on the V4 countries because of the significant changes that occurred in these economies over the last two decades. There is much research dedicated to the ecological situation in post-socialist countries (e.g. Klarer and Moldan, 1997; Andanova, 2003; Šauer et al., 2013), but none of the papers focus on carbon dioxide emissions embodied in international trade. Central and Eastern European countries suffered from many environmental problems and air pollution had been considered the major issue. Due to

\footnotetext{
${ }^{1}$ The Visegrad Group, also called the Visegrad Four (V4), is an alliance of four Central European countries, including the Czech Republic, Hungary, Poland and Slovakia
} 
the large role of heavy industry and the high dependence on brown coal power plants, sulphur dioxide and nitrogen dioxide emissions were extremely high (Pavlínek and Pickles, 2004). Since the 1990s, these emissions have dropped significantly: partly due to the economic downturn, but also to industrial restructuring resulting in the decline of heavy industry and the increasing role of services. In terms of power generation, the shift from coal to natural gas, hydroelectricity and nuclear power, further contributed to emissions reduction. The accession to the EU required adaptation to the regulations and norms of the 'aquis communitaire' in many areas, including environmental protection. EU funding has contributed to increased investments in green technologies. In terms of the carbon dioxide emissions embodied in international trade, the changes in industrial production, export destinations, environmental legislation, and the rise of mass consumerism have all contributed to making the case of the V4 countries very interesting.

\section{Methodology and data}

\subsection{Exports of emissions embodied in international trade}

Over the last few years, the quality and availability of data on the production and consumption of $\mathrm{CO}_{2}$ emissions have improved significantly. Such data, however, are only available at highly aggregated product levels. In order to map trade patterns of exports of carbon dioxide emissions similar to the work of Hidalgo et al. (2008), we need to calculate the exported emissions on a highly-detailed product level. We combine several data sources to calculate these emissions. We work only with carbon dioxide emissions from manufacturing (SITC codes 5-8), since almost twothirds of world trade occurs in manufacturing (64\% in 2011, UNCTAD, 2012). Furthermore, manufacturing exports account for almost $90 \%$ of merchandise exports from the V4 countries, and data for manufacturing are available for most countries over longer periods. We use the 3-digit SITC classification: altogether, 527 product categories.

Regarding the international trade data, for the year 1995 we used the World Trade Flows (WTF) data from Feenstra et al. (2005). For 2008, however, these data were not available, so we used the trade data from the UN Comtrade database and adjusted them in the same way as that used by Feenstra et al. (2005). Due to the existence of global production networks and the fragmentation of the production process, trade in intermediate inputs between 1995 and 2005 represented 56\% of goods traded (Miroudot et al., 2009). Since exports can embody inputs produced in other countries, we can only take into account the domestic value-added of exports. This should contribute to more accurate results. For example, in the V4 countries the domestic value-added of exports is on average only $60 \%$, and in some industries it reaches only $40 \%$. The share of domestic value-added embodied in exports for individual countries and industries are taken from OECD TiVA data (OECD, 2015).

The exports of emissions embodied in international trade are calculated for 1995, 2000 and 2008, for all countries for which carbon dioxide emissions from manufacturing were available. Data on the estimation of carbon dioxide emissions embodied in international trade are more demanding than those used in carbon dioxide production. In most of the relevant research (e.g. Peters and Hertwich, 2008; Weber and Matthews, 2007), input-output models, usually using the GTAP database (Narayanan and Walmsley, 2008), are used in order to calculate the emissions embodied in international trade and therein the carbon dioxide consumption of respective countries. In our paper, we use a different approach, referring to a combination of various data sources (similar to Pan et al., 2008). We calculate the export of emissions embodied in international trade in individual countries based on emissions from manufacturing, average carbon intensities of manufacturing sectors, and international trade data.

Three simplifications had to be introduced. They result in a downward bias in emissions exports. As we are interested in general trends and structural changes over time, however, these simplifications should be acceptable. First, we are using only carbon dioxide emissions from manufacturing industries and construction (electricity and heat excluded, not available for earlier years). Globally, the emissions from manufacturing would increase by almost $80 \%$ if emissions from electricity were included, although there are huge differences in individual countries. Second, due to the unavailability of data on shares of exported production in individual countries and industries, we multiplied carbon dioxide emissions from manufacturing by the share of exports in GDP. Thus, if exports in a particular country account for $60 \%$ of GDP, we expect that $60 \%$ of carbon dioxide emissions from manufacturing would be exported. This simplification can overestimate exports of carbon dioxide in countries that do not export carbon-intensive goods, and vice versa. Third, there are large differences in carbon intensities between industry sectors. We used the Eurostat data (Eurostat, 2012) to assess the carbon intensities of individual industries and products. Since these data are only available for some countries, we had to model the intensities for individual countries. We divided the countries into two groups based on the environmental Human Development Index (UNDP, 2012). These two groups are assigned different values of carbon intensities in industries and products.

\subsection{Revealed relatedness between individual products}

In this paper the focus is on measuring relatedness between individual products, which can offer some useful insights in terms of exported emissions. We do not measure balances of carbon dioxide embodied in international trade, which is the predominant method used in the literature (e.g. Ahmad and Wyckoff, 2003, or Peters et al., 2011). The relatedness is measured between international trade flows of carbon dioxide embodied in international trade in manufacturing industries.

This relatedness between products $i$ and $j$ is associated with the revealed comparative advantage (RCA), which measures whether a country $a$ exports more of embodied carbon dioxide in product $i$, as a share of its total export of embodied carbon dioxide, than the average country. This approach combines the classic RCA (Balassa, 1965) with an environmental perspective. The RCA is defined as:

$$
\mathrm{RCA}_{a, i}=\frac{\mathrm{x}_{a, i}}{\sum_{i}^{\mathrm{n}} \mathrm{x}_{a, i}} / \frac{\sum_{c}^{\mathrm{k}} \mathrm{x}_{a, i}}{\sum_{c, i}^{\mathrm{k}, \mathrm{n}} \mathrm{x}_{a, i}}
$$

\footnotetext{
${ }^{2}$ See Supplementary materials for a list of all products and countries
} 
where, product $i$ in a country $a$ is considered to have a RCA if, and only if, RCA $>1$. To simplify the forthcoming quantifications, the RCA values have been transformed into a binary variable. Products with RCA $>1$ have been assigned value 1 , else the value 0 .

For measuring the revealed relatedness between individual products (their RCA), we have chosen the Jaccard similarity measure (sometimes the Dice measure is used, see Novotný and Cheshire, 2012). The Jaccard measure captures the number of countries where both of two analyzed flows of carbon dioxide embodied in a particular product are concentrated (having RCA) relative to the number of countries where at least one of them concentrates. The Jaccard measure between the two products (their carbon dioxide embodied in international trade flows) $i$ and $j$ when analyzing the co-occurrence over $\mathrm{n}$ countries is defined by the following formula:

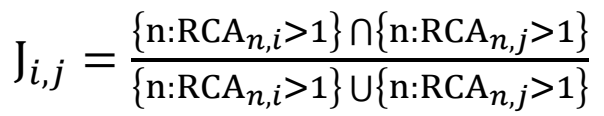

where, the nominator stands for the number of countries where both products $i$ and $j$ satisfy the condition RCA $>1$, while the denominator accounts for the number of countries where at least one product satisfies this condition. The measure can attain values between 0 and 1 . The lower bound means that the carbon dioxide embodied in the two products does not have RCA in any of the countries in the analysis, and the upper bound signifies that the carbon dioxide in the two products is concentrated in identical countries.

\subsection{Product space}

Due to the relatively high number of observations, the resulting matrix with binary relative relatedness values is very large and difficult to interpret. Moreover, the matrix is full of unimportant results close to 0 . Therefore, it is useful to introduce some data mining methods. For this purpose, we have used Cytoscape ${ }^{3}$, open source software, which can visualize large datasets in a form of a network. For visualization, we have chosen the force-directed algorithm. This network can be understood as system of nodes (individual products), which are attracted to each other relative to their revealed relatedness. The nodes are thus distributed within the network in a way which corresponds with the values of measured revealed relatedness between all pairs of nodes and with, if understood as a physical system, minimum energy needed for this arrangement.

This network would not be, due to the high number of pair relations, intelligible. A threshold, which would cutoff unimportant values, must be introduced. According to some authors (Novotný and Cheshire, 2012), inspecting the frequency distribution is suitable for this purpose. The threshold $\mathrm{J}_{\mathrm{i}, \mathrm{j}}$ (denoted as $\mathrm{T}$ ) is then selected according to a clear break in the graph. The number of $\mathrm{m}$ product-product relations can be thus written as:

$$
\mathrm{m}=\mathrm{N}\left(\mathrm{J}_{i, j} \geq \mathrm{T}\right)
$$

The network captures the pattern of carbon dioxide embodied in international trade (i) for a selected year, and (ii) for the global system as a whole. Nonetheless, there are some possibilities in how to approach changes in time and to highlight specific countries or regions within the product space methodology.

Once the product space is constructed, it is also relatively easy to capture the position of individual countries. Within the network, the products where countries under analysis have developed RCA can be highlighted and compared across years. The product space network must be static, i.e. fixed for a specific year, so that we can easily assess the changes. When studying the structural changes of countries, we have used the product space from 2008 as a background network.

\section{Results}

\subsection{Carbon dioxide emissions embodied in international trade}

The V4 countries are in general small export-oriented countries, where the share of exports to GDP has been increasing steadily. Since the 1989 transition, they have become integrated into the global economy. Their participation in global value chains is among the highest in the world and reaches 60\% (OECD, 2015a). This means that $60 \%$ of their exports either contain inputs produced in other countries (the so-called backward participation, which reaches around 40\%) or are intermediate inputs used in exports of third countries (forward participation reaches around 20\%). Thus, due to their large involvement in international trade, focusing on emissions embodied in trade has an important relevance for these economies. To recount, Central and Eastern European countries had widespread ecological problems during the socialist period (Carter and Turnock, 2002), but since 1989 the ecological situation has improved significantly, because of several factors such as economic decline, industrial restructuring or stricter environmental legislation. On the other hand, economic growth has been also associated with negative environmental effects, including higher consumption or increase in car traffic. Assessing how these changes affected air pollution is yet another reason to specify why exploring carbon dioxide emissions embodied in trade is important.

Trade imbalances and differences in carbon-intensity techniques used in production, are responsible for the fact that emissions associated with consumption exceed those from production in most developed countries. Between 1995 and 2008, the number of net exporters of carbon dioxide emissions decreased. The fact that emissions embodied in international trade should globally equal zero indicates that net exporters such as China, the Russian Federation or Saudi Arabia exported more carbon dioxide emissions than before. The V4 countries belong to a group of countries that have become net importers of $\mathrm{CO}_{2}$ emissions over this period.

Between 1995 and 2008 the production of carbon dioxide emissions slightly decreased in all V4 countries (by 5-10\%). The consumption of carbon dioxide emissions on the other increased steadily. In Poland, this growth was the highest and $\mathrm{CO}_{2}$ consumption increased by $24 \%$, whereas in the Czech Republic it increased only by $7 \%$. The difference between consumption and production is measured by the balance of emissions embodied in trade (BEET). In 1995, all V4 countries were net exporters of $\mathrm{CO}_{2}$ emissions since their production exceeded consumption. Hungary became

\footnotetext{
${ }^{3}$ See http://cytoscapeweb.cytoscape.org/documentation/layout
} 


\begin{tabular}{|c|c|c|c|c|c|c|c|c|}
\hline \multirow[b]{2}{*}{ Country/MT $\mathrm{CO}_{2}$} & \multicolumn{4}{|c|}{1995} & \multicolumn{4}{|c|}{2008} \\
\hline & 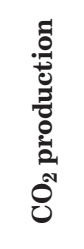 & 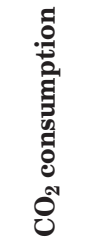 & 仝 & 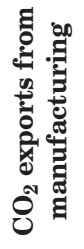 & 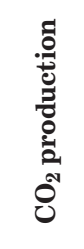 & 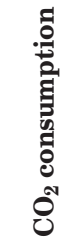 & 㫐 & 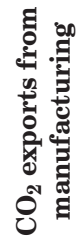 \\
\hline Czech Republic & 124 & 110 & 14 & 12 & 117 & 117 & 0 & 13 \\
\hline Hungary & 57 & 56 & 1 & 4 & 53 & 67 & -14 & 6 \\
\hline Poland & 331 & 285 & 46 & 15 & 299 & 313 & -14 & 15 \\
\hline Slovak Republic & 41 & 34 & 7 & 6 & 36 & 42 & -6 & 8 \\
\hline Germany & 868 & 1,030 & -162 & 31 & 800 & 929 & -129 & 57 \\
\hline United States & 5,139 & 5,384 & -245 & 101 & 5,587 & 6,223 & -637 & 82 \\
\hline China & 2,986 & 2,599 & 387 & 481 & 6,507 & 5,205 & 1,302 & 758 \\
\hline
\end{tabular}

Tab. 1: Carbon dioxide emissions in selected countries (Mt). Sources: OECD (2015); authors' calculations

net importer of $\mathrm{CO}_{2}$ emissions in 2000. In 2008, all V4 countries are net importers of carbon dioxide emissions embodied in trade, and only in the Czech Republic is the BEET equal to zero (see Tab. 1). Due to the differences in population size of the V4 countries, Hungary is the largest net importer of $\mathrm{CO}_{2}$ emissions per person, though in absolute terms the consumption is equal to Poland. The Czech Republic has highest production and consumption of $\mathrm{CO}_{2}$ per person. According the newer data from 2011, the Czech Republic has remained a net exporter of carbon dioxide emissions, whereas the other V4 countries continue to be net importers. The main reason is the fact that only in the Czech Republic has consumption decreased in comparison to the year 1995 (OECD, 2015c). One explanation could be that in the Czech Republic half of the consumption of carbon dioxide emissions emitted abroad originates from the OECD countries, while in the remaining V4 countries it is from non-OECD countries. As soon as detailed data become available, this aspect should be explored in detail.

Differences between the V4 countries are affected by many factors, including the types of resources used for power generation or consumer behavior. According to OECD data (OECD, 2015b), direct carbon dioxide emissions by households have been decreasing in all of these countries except Slovakia. This is probably caused by gasification and the introduction of new and energy-efficient technologies in general. On the other hand, household carbon dioxide emissions by road, per person, have almost doubled in all V4 countries, although the smallest increase can be observed in Hungary. In the Czech Republic, the number of passenger cars has doubled since the transition, whereas in Hungary the number of passenger cars increased at the slowest rate over the studied period (World Bank, 2015). Industry is another important factor affecting production of carbon dioxide emissions. The exports of emissions from manufacturing production did not change much between 1995 and 2008. The largest exporters are Poland and the Czech Republic, whereas exports per person are highest in Slovakia and the Czech Republic. Industrial orientation also plays an important role due to the differences in carbon intensities. An analysis of industries where V4 countries have revealed comparative advantage in exports of embodied emissions from manufacturing can help to explain this. This is elaborated in greater detail in section 4.3 , below.
In Table 1, three other countries are identified: Germany, the United States and China. Thus a first-level comparison can be made with the situation in the $\mathrm{V} 4$ countries. In general, except for Estonia, Luxembourg and the Netherlands, all OECD economies are net importers of carbon dioxide emissions. On the other hand, emerging economies are usually net exporters. China is the largest net exporter of carbon dioxide emissions - and the world's leading polluter as well. Its carbon dioxide production is increasing at a much faster rate than its consumption. Despite the fact that the number of passenger cars is increasing at a rapid pace and causes problems in local cities (Ji et al., 2012), emissions of households per road and person are still low in international comparisons. In the case of Germany, production is also decreasing although manufacturing still plays a key role. One of the reasons for this is similar to the situation in the V4 countries - industrial restructuring and the introduction of greener technologies in the former Eastern Germany (Ebelt et al., 2001). The other reason is probably the attention Germany pays to the environment and sustainable energy, in Germany known as 'Energiewende'. The United States represent a country where both production and consumption of carbon dioxide emissions is growing. Since the United States did not ratify the Kyoto protocol, it does not have any binding targets. In comparison to other EU countries, the V4 countries show a more rapid decrease in GHG emissions per unit of GDP in the period 1999-2009 (-4.7\% versus $-2.9 \%$ ). This can be attributed largely to economic and political transformations. The carbon dioxide emissions were still high in 1999 and due to rapid economic growth in the following years, the emissions intensity decreased, whereas the total emissions declined only slightly (Šauer et al., 2013).

In this paper we used data from the OECD and our own calculations. In other studies (e.g. Ahmad and Wyckoff, 2003; Peters and Hertwich, 2008; or Nakano et al., 2008), the balance of emissions embodied in international trade (BEET) was also calculated. The trends in individual countries are the same and numbers differ only slightly.

\subsection{Product space of embodied emissions}

In this section, the network analyses for carbon dioxide emissions embodied in international trade between 1995 and 2008 are presented.

From a first look, several distinctive groups can be identified. On a right-hand side, there is a large cluster comprising 


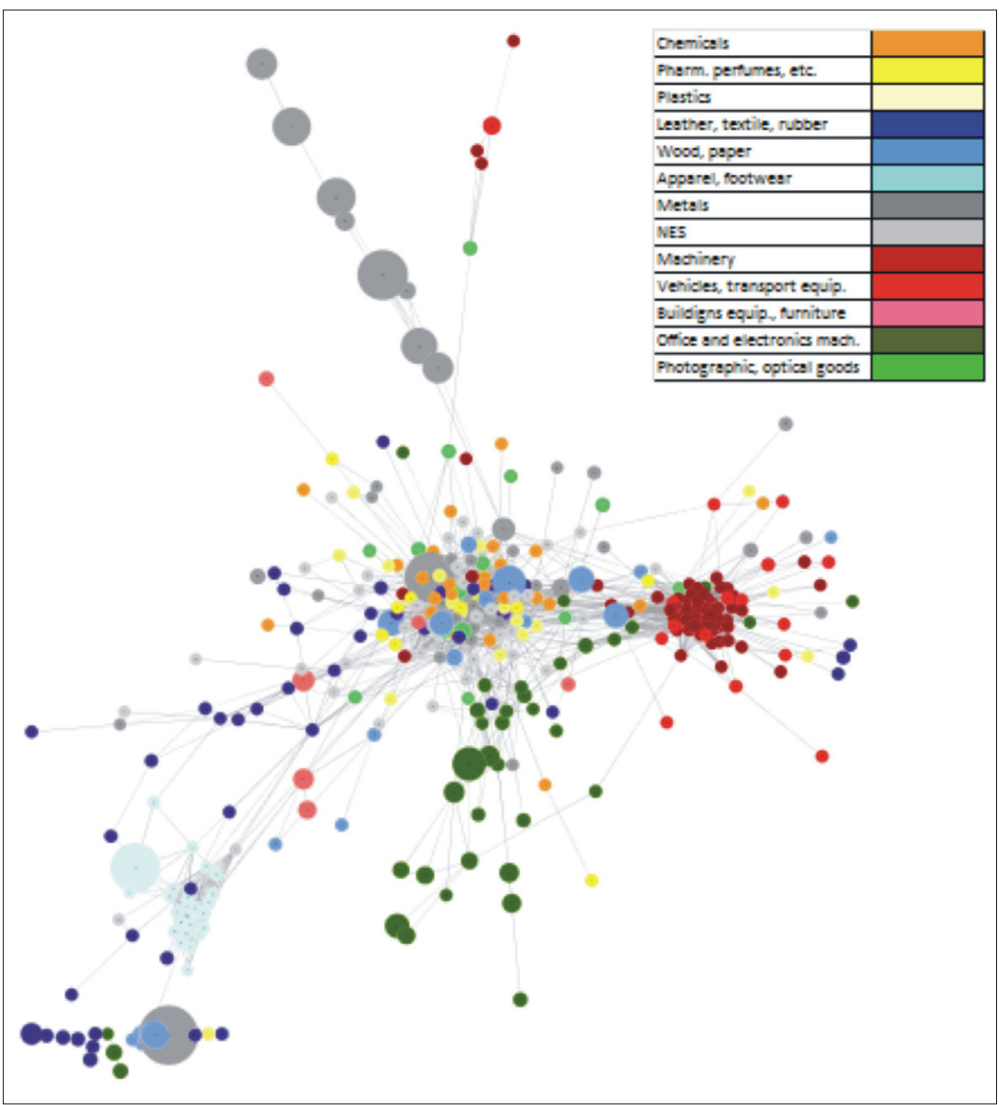

Fig. 1: Product space of embodied emissions in export 1995. Note: Altogether 375 nodes and 3,015 edges; colors of respective nodes represent different groups of sectors, width of edges the revealed relatedness between nodes, and size of the nodes volume of embodied emissions; some peripheral parts of the graph had to be cut off; full-scale figure is downloadable at supportive material at https://www.dropbox.com/sh/1amx5fwz1t16cwy/AADV9r21ppdBB9zO95Stf4 $V q a$ ?dl=0\#. Source: own construction (using Cytoscape 2.8.0); force-directed layout

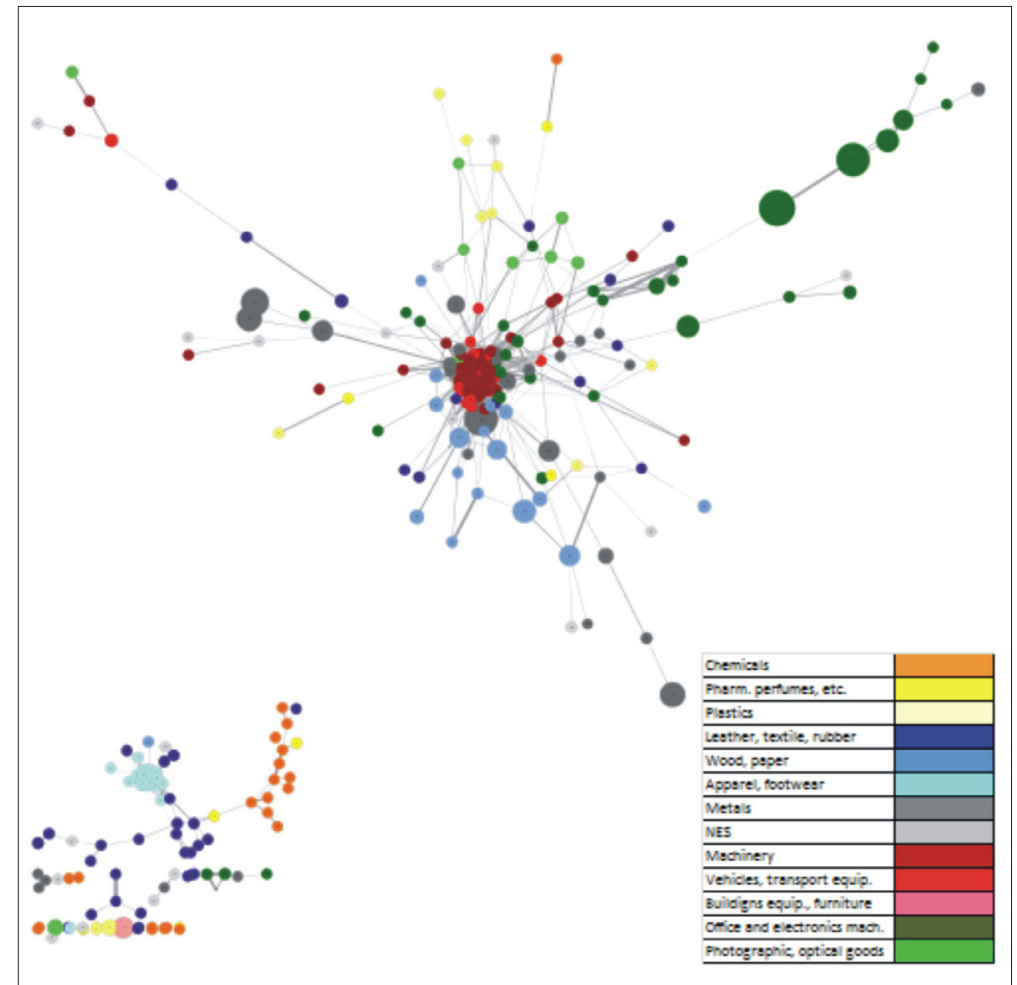

Fig. 2: Product space of embodied emissions in export 2008. Note: Altogether 299 nodes and 2,975 edges; colors of respective nodes represent different groups of sectors, width of edges the revealed relatedness between nodes, and size of the nodes volume of embodied emissions; some peripheral parts of the graph had to be cut off; full-scale figure is downloadable at supportive material at https://www.dropbox.com/sh/1amx5fwz1t16cwy/AADV9r21ppdBB9zO95Stf4 Vqa?dl=0\#. Source: own construction (using Cytoscape 2.8.0); force-directed layout 
machinery (dark red) and transport equipment (light red). At the bottom, there is a cluster of office and electronic machinery (dark green). At the top there is a cluster of nodes belonging to metals (dark grey). On the left-hand side, there is a clearly separated cluster representing the apparel and footwear sector (light blue), which is near another distinctive group even though not that tightly connected - textile yarn, fabrics, and made-up articles (dark blue). Other industries, such chemicals (orange), pharmaceuticals (yellow) or wood and paper (medium blue), are sparsely distributed.

The three significant groups (dark red machinery, light blue apparel, and dark green electronics) imply that traded carbon dioxide emissions are similar across world countries, especially in case of these industries. When studying respective sectors in detail ${ }^{4}$, it seems that similar sectors tend to have similar levels of carbon dioxide embodied in international trade; however, it is never as significant as in case the afore-mentioned three groups.

Moreover, it might by hypothesized that these three groups can to some degree represent complexity (in terms of the volume of added-value) - the core of the "machinery" cluster representing highly complex sector, the "electronics" sector medium complexity, and the "apparel" cluster plus other loosely-connected sectors less complex sectors. This hypothesis can be supported by analysis of revealed comparative advantages of selected countries discussed further in the text.

In 2008 , the general pattern is the same again - the machinery and transport equipment cluster in the middle, the apparel-shoe cluster on the left-hand side, and the electronics cluster on the left. The biggest change is seen in the volume of interrelationships. Compared with 1990, many less nodes (i.e. sectors) are included in the network. This might be caused by increasing differences between strongly integrated clusters (machinery, and footwear and apparel) on one side, and weak relations between other sectors on the other. Due to our applied methodology (with a cut-off according to the distribution curve), many of the sectors had to be omitted from the network. There is still a visible cluster of office and electronic machinery, and partly the leather, textile, and rubber sectors. The large clusters (machinery and apparel) are no longer connected in the network, and it might be expected that they will move further away. In general, there are two significant clusters, machinery and apparel. In machinery, mostly developed countries and net importers of carbon dioxide emissions have a competitive advantage (with a few exceptions, such as Estonia or Lithuania). On the other hand, in apparel and footwear, developing and emerging countries have RCAs, among them major exporters of carbon dioxide emissions like China and India, as well as importers of carbon dioxide belonging to the least developed countries.

In the case of the network based only on trade for the year 1995 (see Figure S1 in supplementary material), there are only two visible clusters - electronics and footwear. Nodes from other industries are highly dispersed in the network. The similarity of the international trade matrix and the exported embodied emission matrix, as measured by Pearson's coefficient of correlation, equals 0.15 in $1995,0.18$ in 2000 and 0.42 in 2008 . These statistical measures indicate that the patterns of embodied carbon dioxide have become closer to patterns of international trade.

\subsection{The position of the V4 countries within the product space}

In this section, we study the position of the V4 countries within the networks presented above. For a specific country, its RCA in carbon dioxide export may be visualized in the network. Moreover, if the network is fixed for a certain year (1995 in our case) the evolution of comparative advantages during the study period may be analyzed, and future trajectories predicted. We can expect the greatest changes in the case of countries with significant economic and/or political changes throughout this period. Clearly, the V4 countries have witnessed such changes during the socioeconomic transformation between 1995 and 2008 .

The first country under analysis is the Czech Republic. In this case, the structural change in exported carbon dioxide is very significant. In 1995, the RCA in exported carbon dioxide (meaning sectors with relatively more exported carbon dioxide when compared with other sectors) is mainly in metals, chemicals, and leather and textile. Even though heavy machinery dominated Czech industry before 1989, economic decline and restructuring was relatively quick and before 1995 many large companies went out of business or decreased production (Pavlínek and Pickles, 2002). In 2000, the situation is very similar to the situation in 1995. In 2008, the red nodes shifted in the figure towards machinery and vehicles and transport equipment. By 2008, the Czech Republic lost RCA in carbon dioxide exports in chemicals and textile. The manufacture of chemicals is an industry with the highest carbon intensities, but for textiles the opposite is true. Despite that, the share of exports of goods and services as a percentage of GDP has been steadily increasing (from $39 \%$ to $64 \%$ over the study period). This indicates major structural changes in the economy. In comparison to other V4 countries, the Czech Republic has RCA in more product categories over the whole period. This is probably one of the reasons why the Czech Republic has not yet become a net importer of carbon dioxide emissions.

In 1995, the Slovak Republic had RCA in exported carbon dioxide emissions only in a few industries (product categories), and most of them belonged to either metals or textiles and the leather industry. In 2000, the number of industries with RCA decreased further; however, in 2008 the structure had changed significantly. In terms of carbon dioxide emissions, the RCA is mostly in machinery, metals, vehicle and transport equipment, but in office and electronics as well.

Another transition economy, Hungary, experienced large changes too. In 1995, Hungary had RCA only in apparel and footwear, and wood and paper. In 2000, there is a move towards machinery and electronics. In 2008, this is further amplified and machinery and electronics belong to the sectors with the highest number product categories with RCA. In this respect, Hungary differs from the other V4 countries since it does not have RCA in transport equipment industry. This can be attributed to the fact that the automotive industry is the largest exporting industry in all V4 economies except Hungary (OECD, 2015b).

Even more significant changes can be observed in Poland. In 1995, there are RCAs in carbon dioxide exports only in several sectors even though Poland is one of the largest net exporters of embodied emissions. The RCAs are mainly in leather, the textile and rubber industry, and in metals exports. In 2008, more sectors in Poland have RCAs in carbon dioxide export. It has shifted from metals

\footnotetext{
${ }^{4}$ The figure in full-scale is available at: https://www.dropbox.com/sh/c3vqi6666rozn48/SKgocnonfT
} 


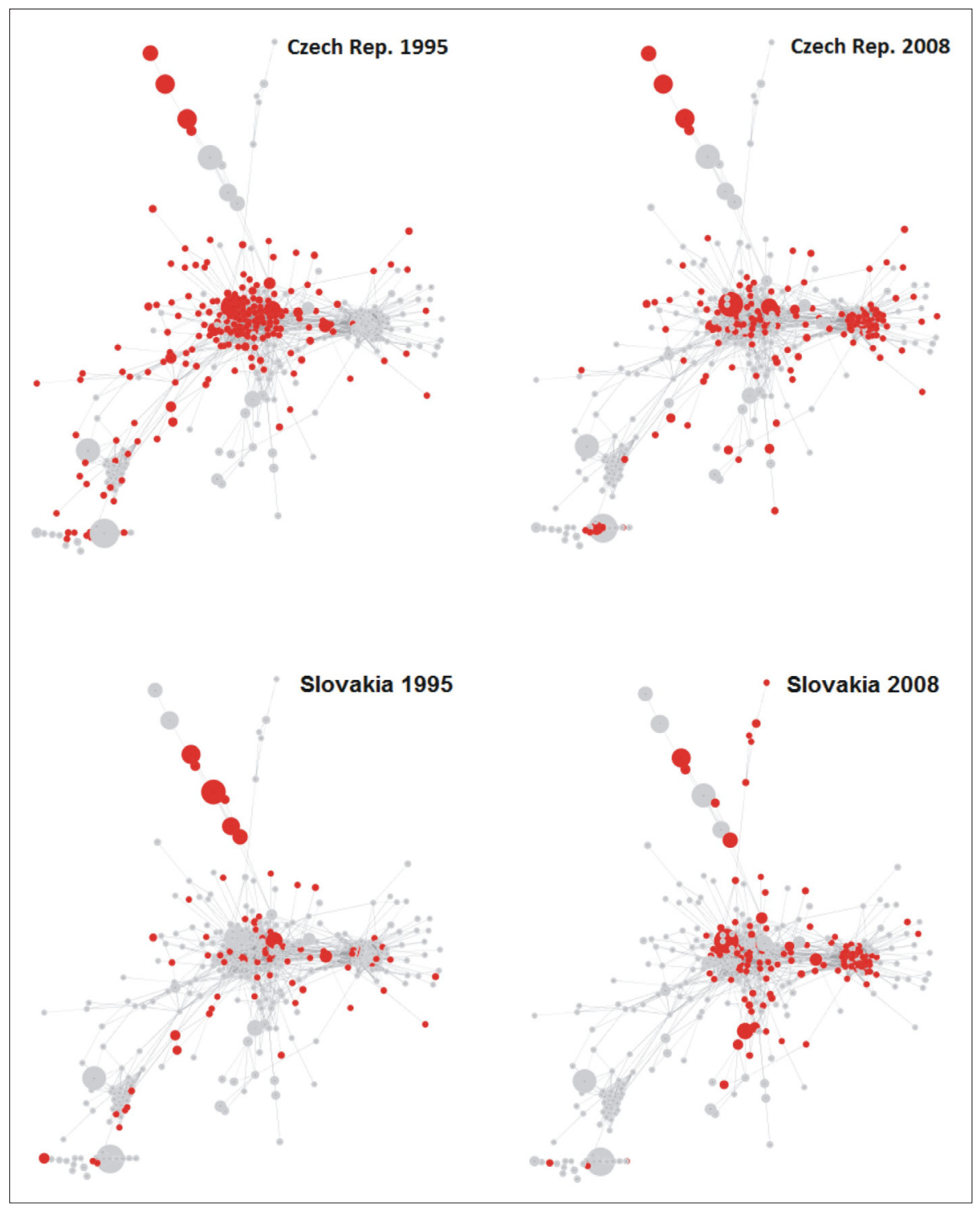

Fig. 3: Product space of embodied emissions in export 1990-2008 (Czech Republic, Slovak Republic). Notes: Within the network, red nodes depict the products where countries under analysis have developed comparative advantage. The product space network from 2008 is fixed so that we can easily assess the changes. Some peripheral parts of graphs had to be cut off; https://www.dropbox.com/sh/1amx5fwz1t16cwy/AADV9r21ppdBB9zO95Stf4Vqa ? $d l=0 \#$. Source: own construction (using Cytoscape 2.8.0); force-directed layout

and leather, and the textile and rubber industry, towards machinery, vehicles and transport machinery, and office and electronics machinery sectors. Quite paradoxically, even though the number of sectors with RCA in carbon dioxide emission has risen over time, Poland has become net importer of emissions embodied in international trade. This can be explained by the growth of purchasing power and the volume of international trade as such. Similar to Slovakia and Hungary, the change in carbon dioxide consumption/ production structure (net exporters becoming net importers) seems to be a standard trajectory of a transition towards a more developed (consumption-oriented) economy.

In general, in all V4 countries, there is an obvious shift away from the leather and textile, metals and chemicals clusters - towards the machinery and transport equipment industry. In Hungary or Slovakia, the electronics industry is also more significant in terms of RCA in exported emissions. In the Czech Republic, the electronics industry exports contain $60 \%$ of foreign value-added (OECD, 2015a). Since in our calculations we take only domestic value- added exports into account, this is probably the reason why the Czech
Republic does not have RCA in exported emissions in this industry. A common feature of the V4 countries is a move away from carbon-intensive industries (such as chemicals and metals) to the less carbon-intensive industries. This corresponds with the FDI inflows, which were directed towards export-oriented industries, especially the automotive industry due to their comparative advantage in assembly and labour-intensive manufacturing (Humphrey et. al., 2000). The EU accession surely played an important role in the changes that occurred between 2000 and 2008, since it was accompanied by the largest FDI inflow over the period in all V4 countries (UNCTAD, 2012). This industrial restructuring definitely contributed to the decrease in carbon dioxide emissions production. Furthermore, despite the fact that exports as a percentage of GDP almost doubled over the studied period, carbon dioxide emissions from manufacturing embodied in exports increased only slightly. The calculations of exported emissions are based on value-added exports. Despite that, RCA in exported emissions differs slightly from the RCA based on the value-added exports. For example, Poland still has RCA 


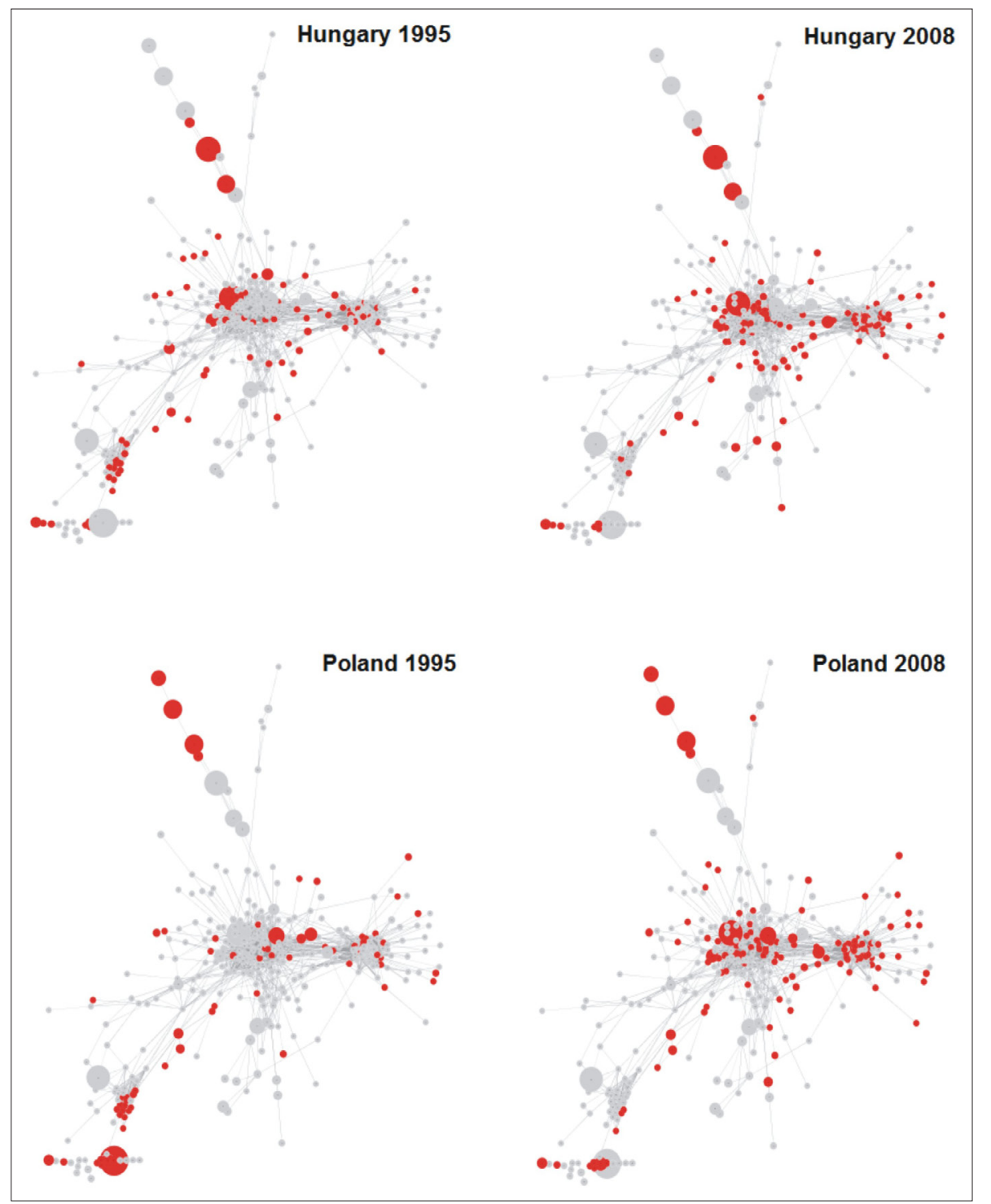

Fig. 4: Product space of embodied emissions in export 1990-2008 (Hungary, Poland). Note: Within the network, red nodes depict the products where countries under analysis have developed comparative advantage. The product space network from 2008 is fixed so that we can easily assess the changes. Some peripheral parts of graphs had to be cut off; https://www.dropbox.com/sh/1amx5fwz1t16cwy/AADV9r21ppdBB9zO95Stf4Vqa?dl=0\#. Source: own construction (using Cytoscape 2.8.0); force-directed layout

in manufacturing NEC (not elsewhere specified) based on value-added exports. Based on the network analysis, we can also predict future trajectories in terms of exported carbon dioxide emissions. The networks indicate that the exported carbon dioxide emissions in terms of RCA will further concentrate in machinery and transport industries, and in some countries also to the electronics industry.

\section{Conclusions}

In this paper, we have studied the carbon dioxide emissions embodied in international trade, with special attention to Central European countries. The main goal was to assess the changes in these countries in terms of emissions production and consumption. Major attention was given to the manufacturing sector.

Globally, since 1990 there have always been more net importers than net exporters. This disparity has been steadily rising. This means that fewer countries are responsible for the amount of carbon dioxide embodied in international trade, even though the volume of embodied emissions as such is rising (most significantly in China). Generally, BEET has changed mostly in countries which have experienced important political or/and economic changes, such as the Central European countries. At the beginning of the transformation period in 1989, all V4 countries were exporters of carbon dioxide emissions. Despite the fact that production of emissions decreased slightly in all countries, the consumption of $\mathrm{CO}_{2}$ emissions increased at a faster pace. Several factors contributed to the decrease in carbon dioxide emissions. Economic decline, industrial restructuring, the introduction of environmental legislation and less carbon intensive technologies, are probably the major ones. On the other hand, growing incomes, preferences for foreign consumer goods and an increase in the number of passenger cars, contributed to the growth in consumption of carbon dioxide emissions. Over time, all the V4 countries except the Czech Republic became net importers of carbon dioxide emissions. The change in carbon dioxide consumption/ production structure (net exporters becoming net importers) appears to be the 'standard trajectory' of a transition toward a more developed and consumption-oriented economy. 
Furthermore, we explored patterns of these embodied emissions through a network analysis. Based on the application of several data sources, such as international trade data, domestic value-added embodied in exports, carbon dioxide emissions from manufacturing and carbon intensities of individual industries, we calculated carbon dioxide emissions embodied in trade for 128 countries at a highly disaggregated product level (527 product groups). We limited our analyses to manufacturing industries, where the majority of traded (embodied) carbon dioxide emissions occur.

We used these balances for studying patterns of embodied emissions through network analysis. Within this network, product space, the sectors with similar exporting structure cluster, are recorded. This similarity was based on relative comparative advantages (RCAs) of individual countries in the export of carbon dioxide emissions. In other words, sectors which are exported by similar countries and at the same time these countries export relatively more embodied emissions than other countries in these sectors, are considered similar and are clustered in the network. These networks also help to explain the changes in carbon dioxide production, since industrial orientation plays an important role in terms of exports of emissions embodied in trade due to the differences in carbon intensities. Within the product space, three main clusters appeared. One cluster comprises predominantly the machinery sectors, the second one the textile and apparel sectors, and the third sector represents electronics. Other sectors are clustered less significantly or not at all. Moreover, these three largest clusters drifted apart, indicating more intensive specialization. Interestingly, the correlation between trade network and emissions exports has risen significantly during the study period.

Finally, we studied the evolution of RCAs in exported carbon dioxide emissions in the V4 countries. These countries (unlike other countries such as United States) showed significant shifts of these RCAs. In 1995, V4 countries had RCAs in $\mathrm{CO}_{2}$ exported emissions in industries such as metals, chemicals, and textile and leather. In 2008, they have RCA mostly in the vehicle and transport equipment, machinery, and electronics industries. This is consistent with FDI inflows, which were directed mainly towards the automotive industry (Pavlínek et al., 2009; Humphrey et al., 2000). In addition, the automotive and machinery industry are closely connected, since many supplying companies of car producers belong to the machinery industry. These industries have lower carbon intensities, whereas metals and chemicals have the highest carbon intensities. Industrial restructuring is thus probably the major reason why exported emissions increased only slightly in the V4 countries, whereas the share of exports to GDP almost doubled over the study period. The differences in industrial orientation and exported $\mathrm{CO}_{2}$ emissions between the V4 countries are small: for example, the electronics industry is less important in the Czech Republic, whereas transport equipment is less represented in Hungary. RCAs in carbon dioxide emissions differ slightly from RCA based on value-added exports.

There are several avenues for future research. First of all, the methodology can be improved and more sophisticated modelling can be introduced. More attention should be given to changes in consumer patterns in the transition countries. Furthermore, the impacts of increased attention given to the reduction of carbon dioxide emissions and increased energy efficiency in the EU set in the goals of strategy Europe 2020, should be explored in the V4 countries. There is relevant public support for environmental projects such as the "Green Saving Programme", targetted at energy efficiency in the Czech Republic, and its impacts on BEET would be very interesting. Moreover, the time span of the analysis may be extended in order to account for the impacts of economic crises, especially in relation to the global slump in international trade, which was surprisingly accompanied by growth in carbon dioxide emissions after the crises (Peters et al., 2012)

These findings have some important practical implications. First of all, it should be considered whether the responsibility for global emissions should be assessed solely according to their production, or whether also consuming of emissions embodied in international trade, should be controlled. Despite academic discussions regarding the importance of the "consumption" of carbon dioxide emissions (Peters and Hertwich, 2008; Turner et al., 2007 etc.), the extension of the Kyoto protocol from the U.N. Framework Convention on Climate Change conference held in 2012 in Doha, did not result in any changes in this respect. But, the consumption of goods in economies which like to consider themselves as 'clean' (such as Germany), implies production of these emissions elsewhere, typically in China. Since some of these emissions (carbon dioxide above all) are global and thus affect the whole planet, even the "clean economies" are responsible for the detrimental effects of carbon dioxide produced in China, such as global warming. We believe that more scientific and political attention should be given to this problem.

\section{Acknowledgement}

The authors acknowledge support from the Czech Science Foundation through research grant: 'International division of labour and the competitiveness of Czech economy, regions, and firms' - (P402/11/1712) and support from the Foundation of Josef, Marie and Zdeňka Hlávka.

\section{References:}

AHMAD, N., WYCKOFF, A. (2000): Carbon dioxide emissions embodied in international trade of goods. No. 2003/15. OECD Publishing.

ANDANOVA, L. B. (2003). Transnational politics of the environment: The European Union and environmental policy in Central and Eastern Europe. MIT Press.

BALASSA, B. (1965): Trade Liberalisation and "Revealed" Comparative Advantage1. The Manchester School 33(2): 99-123.

BIVENS, J. (2007): Globalization, American Wages, and Inequality: Past, Present, and Future. EPI Working Paper 279. Washington: Economic Policy Institute.

CARTER, F., TURNOCK, D. (2002). Environmental Problems in East-Central Europe (Vol. 16). IAP.

DICKEN, P. (2007): Global shift: Mapping the changing contours of the world economy. SAGE Publications Ltd.

EBELT, S., BRAUER, M., CYRYS, J., TUCH, T., KREYLING, W. G., WICHMANN, H. E., HEINRICH, J. (2001). Air quality in postunification Erfurt, East Germany: associating changes in pollutant concentrations with changes in emissions. Environmental Health Perspectives, 109(4): 325.

EIA (2012): $\mathrm{CO}_{2}$ Emissions from Fuel Combustion, Edition 2011 [online]. [cit.14.12.2013] Available at: http://www. iea.org/co2highlights/CO2highlights.pdf 
EUROSTAT (2012): Greenhouse Gas Emissions [online]. [cit.14.12.2013] Available at: http://epp.eurostat.ec.europa. eu/portal/page/portal/environment/data/database

FAGERBERG, J. (1994): Technology and International Differences in Growth Rates. Journal of Economic Literature, 32(3): 1147-1175.

FEENSTRA, R. C., LIPSEY, R. E., DENG, H., MA, A. C., MO., H. (2005): World trade flows: 1962-2000. NBER Working Paper 11040.

GROSSMAN, G., HELPMAN, E. (1991): Innovation and Growth in the Global Economy. Cambridge, MA: MIT Press.

GROSSMAN, G., ROSSI-HANSBERG, E. (2008): Trading tasks: A simple theory of offshoring. NBER Working Paper 12721

GUTMAN, P. (1994): Developing countries and international environmental negotiations: The risks of poorly informed choices. Society \& natural resources, 7(4): 389-397.

HELPMAN, E. (2011): Understanding global trade. Harvard University Press.

HEMMELSKAMP， J. (1997): Environmental policy instruments and their effects on innovation. European Planning Studies, 5(2): 177-194.

HOEKSTRA, A. Y., HUNG, P. Q. (2005): Globalisation of water resources: International virtual water flows in relation to crop trade. Global Environ. Change 15(1): 45-56.

HIDALGO, C. A., KLINGER, B., BARABÁSI, A. L., HAUSMANN, R. (2007): The product space conditions the development of nations. Science, 317(5837): 482-487.

HUBACEK, K., GILJUM, S. (2003): Applying physical input-output analysis to estimate land appropriation (ecological footprints) of international trade activities. Ecological Economics, 44(1): 137-151.

JI, S., CHERRY, C. R. J., BECHLE, M., WU, Y., MARSHALL, J. D. (2012): Electric vehicles in China: emissions and health impacts. Environmental science \& technology, 46(4): 2018-2024.

JORGENSON, A. K., CLARK, B., GIETRAITS, V. R. (2012): The Temporal (In)Stability of the Carbon Dioxide Emissions/Economic Development Relationship in Central and Eastern European Nations. Society \& Natural Resource, 25(11): 1182-1192.

KLARER, J., MOLDAN, B. (1997). The environmental challenge for Central European economies in transition. John Wiley \& Sons.

KRUGMAN, P. (1980): Scale Economies, Product Differentiation, and the Pattern of Trade. The American Economic Review, 70(5): 950-959.

LIN, B., SUN, C. (2010): Evaluating carbon dioxide emissions in international trade of China. Energy Policy, 38(1): 613-621.

METZ, B. [ed.]. (2007): Climate change 2007: mitigation: contribution of working group III to the fourth assessment report of the intergovernmental panel on climate change. Intergovernmental Panel on Climate Change.

MIROUDOT, S., LANZ, R., RAGOUSSIS, A. (2009): Trade in intermediate goods and services. No. 93. OECD Publishing.

MORIGUCHI, Y. (2002): Material flow analysis and industrial ecology studies in Japan. A handbook of industrial ecology 301.
NAKANO, S., OKAMURA, A., SAKURAI, N., SUZUKI, M., TOJO, Y., YAMANO N. (2009): The measurement of $\mathrm{CO}_{2}$ embodiments in international trade: evidence from the harmonised input-output and bilateral trade database. No. 2009/3. OECD Publishing.

NARAYANAN, B., WALMSLEY, T. L. (2008): Global Trade, Assistance, and Production: The GTAP 7 Data Base. Center for Global Trade Analysis, Purdue University, Washington D. C.

NOVOTNÝ, J., CHESHIRE, J.A. (2012): The Surname Space of the Czechia: Examining Population Structure by Network Analysis of Spatial Co-Occurrence of Surnames. PloS one 7(10): e48568.

OECD (2015a): Trade in value added [online]. [cit 02.07.2015]. Available at: http://stats.oecd.org/Index. aspx?DataSetCode=TIVA2015_C1

OECD (2015b): Carbon Dioxide Emissions embodied in International Trade[online]. [cit10.07.2015].Availableat: https://stats.oecd.org/Index.aspx?DataSetCode=STAN IO_GHG

OECD (2015c): Carbon Dioxide Emissions Embodied in International Trade [online]. [cit 23.07. 2015]. Available at: http://www.oecd.org/industry/ind/ carbondioxideemissionsembodiedininternationaltrade.htm

PAN, J., PHILLIPS, J., CHEN, Y. (2008): China's balance of emissions embodied in trade: approaches to measurement and allocating international responsibility. Oxford Review of Economic Policy, 24(2): 354-376.

PAVLÍNEK, P., DOMANSKI, B., GUZIK, R. (2009): Industrial upgrading through foreign direct investment in Central European automotive manufacturing. European Urban and Regional Studies, 16(1): 43-63.

PAVLÍNEK, P., PICKLES, J. (2004): Environmental pasts/environmental futures in post-socialist Europe. Environmental Politics, 13(1): 237-265.

PETERS, G. P., HERTWICH, E. G. (2008): $\mathrm{CO}_{2}$ embodied in international trade with implications for global climate policy. Environmental Science \& Technology, 42(5): 1401-1407.

PETERS, G. P., MINX, J. C., WEBER, C. L., EDENHOFER, O. (2011): Growth in emission transfers via international trade from 1990 to 2008. Proceedings of the National Academy of Sciences, 108(21): 8903-8908.

PETERS, G. P., WEBER, C. L., GUAN, D., HUBACEK, K. (2007): China's Growing $\mathrm{CO}_{2}$ Emissions: A Race between Increasing Consumption and Efficiency Gains. Environmental Science \& Technology, 41(17): 5939-5944.

PETERS, G. P., MARLAND, G., LE QUÉRÉ, C., BODEN, T., CANADELL, J. G., RAUPACH, M. R. (2012): Rapid growth in $\mathrm{CO}_{2}$ emissions after the 2008-2009 global financial crisis. Nature and Climate Change, 2(1): 2-4.

RAUPACH, M. R., MARLAND, G., CIAIS, P., LE QUÉRÉ, C., CANADELL, G., KLEPPER, C., FIELD, B. (2007): Global and regional drivers of accelerating $\mathrm{CO}_{2}$ emissions. Proceedings of the National Academy of Sciences, 104(24): 10288-10293.

ŠAUER, P. ŠVICHLOVÁ, D., DVOŘÁK, A., ALEŠ, L., KOBYLARCZYK, J. (2013): Visegrad countries: environmental problems and policies. CENIA. 
TURNER, K., LENZEN, M., WIEDMANN, T., BARETT J. (2007): Examining the global environmental impact of regional consumption activities-Part 1: A technical note on combining input-output and ecological footprint analysis. Ecological Economics, 62(1): 37-44.

UNDP (2012): Human Development Report [online]. [cit 02.10.2013] Available at: http://hdr.undp.org/en/statistics/

UNCTAD (2012): UNCTAD Statistics [online]. [cit 02.10.2013] Available at: http://unctadstat.unctad.org/ TableViewer/tableView.aspx?ReportId = 24741

UNFCCC (2009): Press release - Fact sheet: The need for mitigation [online]. [cit.14.12.2013] Available at: http:// unfccc.int/files/press/backgrounders/application/pdf/ press_factsh_mitigation.pdf
WEBER, C. L., MATTHEWS, H. S. (2007): Embodied environmental emissions in US international trade, 1997-2004): Environmental Science \& Technology, 41(14): 4875-4881.

WORLD BANK (2015): Trade statistics [online]. [cit. 07.12.2013] Available at: http://data.worldbank.org

WTO (2011): World Trade in 2010 [online]. [cit. 18.01.2014] Available at: www.wto.org/english/res_e/publications_e/ wtr10_e.htm

\section{Supplementary material:}

https://www.dropbox.com/sh/1amx5fwz1t16cwy/ AADV9r21ppdBB9zO95Stf4Vqa?dl=0\#

Initial submission 3 September 2014, final acceptance 13 November 2015

\section{Please cite this article as:}

VLČKOVÁ, J., NOSEK, V., NOVOTNÝ, J., LUPÍŠEK, A. (2015): Carbon dioxide emissions embodied in international trade in Central Europe between 1995 and 2008. Moravian Geographical Reports, 23(4): 2-13. DOI: 10.1515/mgr-2015-0020. 